\title{
Agronomical and Botanical Characteristics of Cuminum setifolium (Boiss.) Kos.-Pol. a Plant with Potentially Medicinal Applications
}

\author{
Abbas SAFARNEJAD, Masoud ABBASI, Sayed Mohammad TABATABAEI \\ Razavi-Khorasan Agriculture and Natural Resources Research Center. PO. Box.91735-1148. Mashhad, Iran; sebre14@yahoo.com
}

\begin{abstract}
Medicinal plants are the most important source of medicine. Cuminum setifolium (Boiss.) Kos.-Pol. with common name of white cumin, a member of the Apiaceae family, growing wild on mountains was investigated as a species having capability for cultivation and crop breeding. Generally, there is not information about Cuminum setifolium species. The aim of this study was to found plant identification and distribution in Iran, phenology, best treatment for seeds germination, farm cultivation and anatomical description. Cuminum setifolium plant is a annual herb which is distributed in Iran, Turkmenistan, Afghanistan, Pakistan, Tien-Shan and central Asia. In our studied region, the plant is generally grown on calcareous marl soils with climatic conditions of desert cold, semi-arid to arid having hot summer and cold winter. The effects of different treatment on seed germination showed significant highest germination percentage (54.4\%), germination rate $(6.4 \%)$ were obtained from seeds that had exposed for 3 weeks at $4^{\circ} \mathrm{C}$ after omit of seeds hairs. The experiment of cultivation showed the best time for sowing in Mashhad was autumn and growing time was from middle of March until end of June and ripening seeds were end of June at 2005. Microscopic observation of the root structure showed lacking secondary structures and having epidermis tissue with only a row of cells along with relatively thick cuticle and for stem and leaf structure with stomata without any hairs. Parenchyma cells contained 2-3 rows of irregular oblong cells. Stomata type of epidermis was diacytic and distance between stomata was measured $5 \mu \mathrm{m}$ in average.
\end{abstract}

Keywords: anatomical, cultivation, Cuminum setifolium, germination, phenology, Psammogeton setifolius, Torilis setifolia

\section{Introduction}

Nowadays, food industries are paying more attention on the identification of the world's flora, regarding the therapeutic and medicinal uses of diverse plants. Also, various species have applications in agriculture as well, for the use in soil conservation and rehabilitation, as forage crops, and in the perfume industry, to mention only a few. Medicinal plants are the majority of the world's population still relies on the use of plants for healing (Tripathi and Tripathi, 2003). The Umbelliferae (Apiaceae) is a plant family containing approximately 200 genera and 2900 species in the world. Of these, about 100-117 genera and 450 species in found in Iran, which are distributed throughout the country (Mozaffarian, 1983). Cumin (Cuminum cyminum L.), also known by the local names of green cumin and white cumin (Cuminum setifolium Boiss., Kos.-Pol., 1916). Syn. Psammogeton setifolius (Boiss.) Boiss.(1872), Torilis setifolia Boiss.(1856) are the closely related members of the Umbelliferae family. Green cumin (Cuminum cyminum L.) has been cultivated in few countries such as India, Pakistan, Turkey, Iran, Egypt and Spain. It is one of the oldest and economically most important spices (Kafi et al., 2002). White cumin (Cuminum setifolium) grows wild in mountainous areas of various countries such as Iran, Turkmenistan, Afghanistan, Pakistan, Tien-Shan, as well as in central Asia (Mozaffarian, 1983; Rechinger, 1987).
Recent studies suggest that green cumin is one of the species subject to renewed interest as an important medicinal crop (Ebrahimie et al., 2003). Production of green cumin is limited due to several biotic stresses, of which kaphra beetle (Trogoderma granarium) and wilt disease are the most serious (Agrawal, 1996; Champawat and Pathak, 1990). Therefore, white cumin as a wild type may be useful in future studies for improvement of green cumin with cross pollination for obtaining hybrids between them as well as genetic manipulation for finding strains with superior characteristics such as tolerance to disease, pests, drought and salinity, improved growth and development, increased of yield as well as other diverse parameters used in crop production. White cumin is an annual herb, glabrous, 10-30 cm tall, with forked branches; basal leaves sheathed and membranous, leaf blade tripartite, segments filiform, umbel rays 3-4, nearly $5 \mathrm{~mm}$ long; bracts and bracteoles divided, narrowly linear, membranous at margins; calyx teeth conspicuous; flowers white to pink or light red; fruit oblong, 4-5 mm long, densely covered with long simple hairs originated from secondary ridges, hairs 5-7 mm long (Mozaffarian, 1983; Rechinger, 1987). The plant seeds are important in medicinal and therapeutic utilization. Traditionally, the seeds were consumed locally as a spice and carminative drug. Seed dormancy is one of crop obstacles to be cultured widely. Generally Umbelliferae species possess antimicrobial properties (Kafi et al., 2002; Theoblad, 
1971). Breeding techniques for this botanical family can be slow, troublesome and very lengthy employing the classic approach (Hunault et al., 1989). There is no information about white cumin (Cuminum setifolium) except distribution and botanical description (Mozaffarian, 1983; Rechinger, 1987). Because of its pleasant mild aroma and taste, this plant use as a desire condiment cum medicine use. Several therapeutic effects including digestive disorders, urinary tract disorders, anti convulsion, antiasthma and also antimicrobial and antifungal effects have been confirmed in the Cuminum cyminum (Kafi et al., 2002). Although, white cumin is applied for having similar effects with the species in local usage, but there is no report regarding any side effects of that plant or its extract yet.

The aim of this study was to find the plant's identification and distribution in Iran, its phenology, best treatment for germination of seeds, cultivation on the farm and its anatomical description.

\section{Materials and methods}

Identification and distribution of this plant in Iran were investigated during the growth season during 2004 and 2005. For their phenology, and best treatment for seed germination and anatomical description, the seeds and specimens of the fresh plant were collected from wild pistachio forest (Sanganeh, Chahchaheh and Shoorlogh) located in NE Mashhad city during the spring season and were then transferred immediately to Khorasan Agricultural and Natural Resources Research Center Laboratory. Seeds were carefully surface sterilized in $2 \%(\mathrm{v} / \mathrm{v})$ sodium hypochlorite for 15 minutes, washed with distilled water and dried at room temperature. Seeds were cultured on aseptic moist filter paper in a Petri dish and stored at $4^{\circ} \mathrm{C}$ and darkness for 10 weeks. Other treatments such as stratification, gyberlic acid, cytokinin, potassium nitrate, washing and light treatments were also used. Seeds were replicated four times in four separate containers for each treatment. During a period of 10 weeks, germination percentage and rate, as well as radicle and plumule growth were recorded. For the cultivation experiment, the seeds were sown in the farm at autumn. The seeds were germinated during the middle of March and harvested at the end of June of 2005. In order to investigate the anatomical structure of the plant tissues, sample from stem, leaf and root of the fresh plant were obtained. The samples were mounted separately in an F.A.A. solution (Formalin Aceto Alcohol) and after one week were sectioned manually. After that, the sections were stained using methylen blue-carmine. The stained samples were fixed on slides for anatomical observations and photographic preparations using optic microscope equipped with a camera. The experiment was conducted in a completely randomized design and statistical analyses, as well as chart drawing were done using SAS and Excell softwares, respectively. Means comparison were done with Duncan multiple range test with a $5 \%$ probability level.

\section{Results}

\section{Botanical description of Cuminum setifolium}

In the region studied, the plant is usually grown on calcareous marl soils with climatic conditions of desert cold semiarid-arid having a hot summer and a cold winter. The mean annual precipitation is $200-300 \mathrm{~mm}$, the mean annual temperature varies between $12.5-15^{\circ} \mathrm{C}$ with an mean

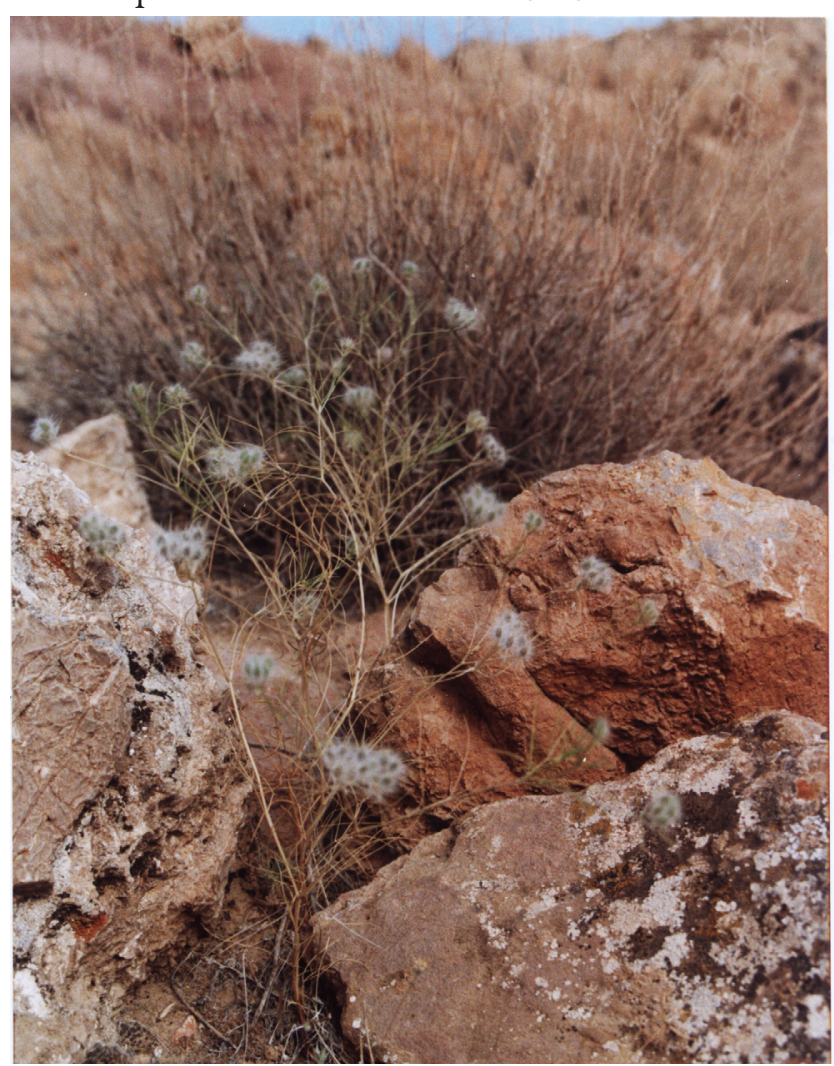

Fig. 1. A wild mature plant of Cuminum setifolium (Boiss.) Kos.Pol. Apiaceae

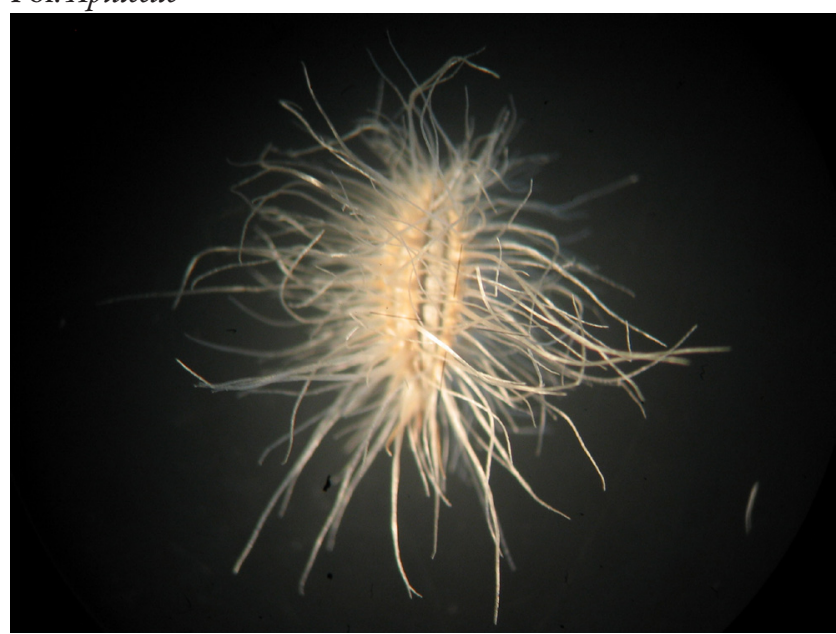

Fig. 2. A seed of Cuminum setifolium (Boiss.) Kos.-Pol., Apiaceae 
32

annual evaporation of 2400-2600 $\mathrm{mm}$. Growing time for the plant was from mid March until the end of June and its flowering time was from early May to June (Fig. 1,2).

The effects of different treatment on seed germination showed significant the highest germination percentage $(54.4 \%)$ and germination rate $(6.4 \%)$ which were obtained from seeds that had exposed for 3 weeks at $4^{\circ} \mathrm{C}$ after omitting the seeds' hairs. Without omitting the seeds hairs, the germination was $(7.42 \%)$ which occurred in seeds which had been exposed for 10 weeks at $4^{\circ} \mathrm{C}$. Other treatments such as stratification, gyberlic acid, cytokinin, potassium nitrate, washing and light treatments did not cause the seed to germinate. The seeds usually were infected by $\mathrm{Al}$ ternaria alternatea and Aspergillus sp.

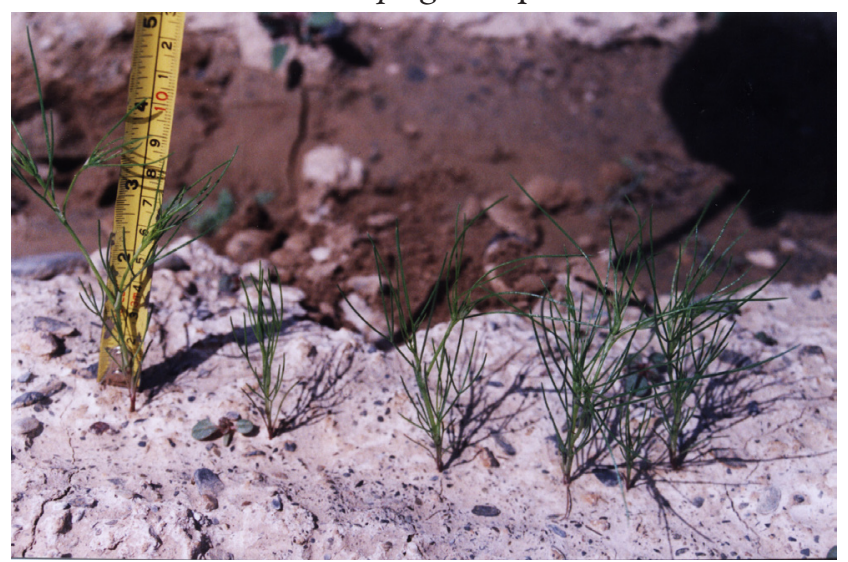

Fig. 3. Cultivated plant of Cuminum setifolium (Boiss.) Kos.Pol. in the farm

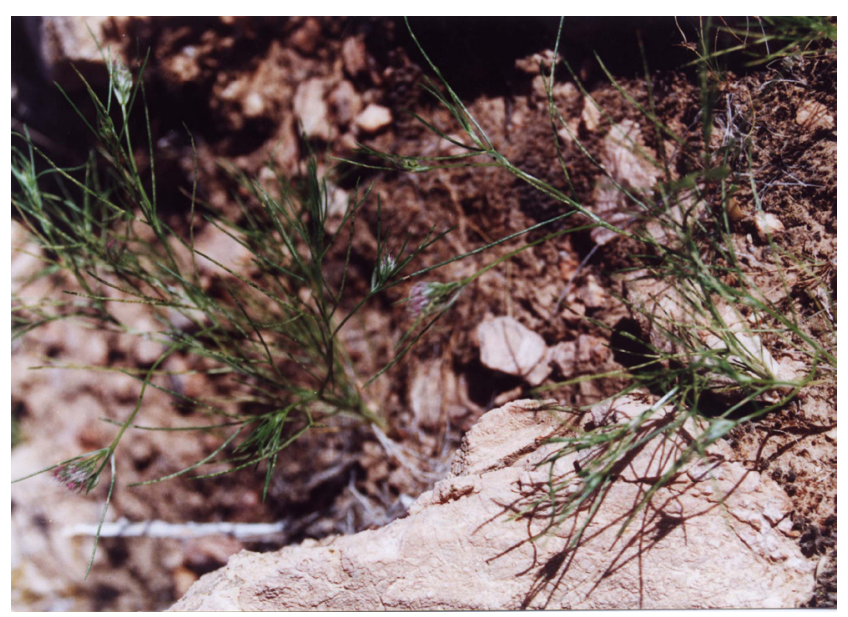

Fig. 4. Flowering plant of Cuminum setifolium (Boiss.) Kos.-Pol. in the farm

For the cultivation experiment, the seeds were germinated during the middle of March and harvested at the end of June of 2005 (Fig. 3, 4, 5).

\section{Anatomical description of Cuminum setifolium}

\section{Root structure}

Microscopic observation of the root sections showed a lack of secondary structures and the presence of epidermis

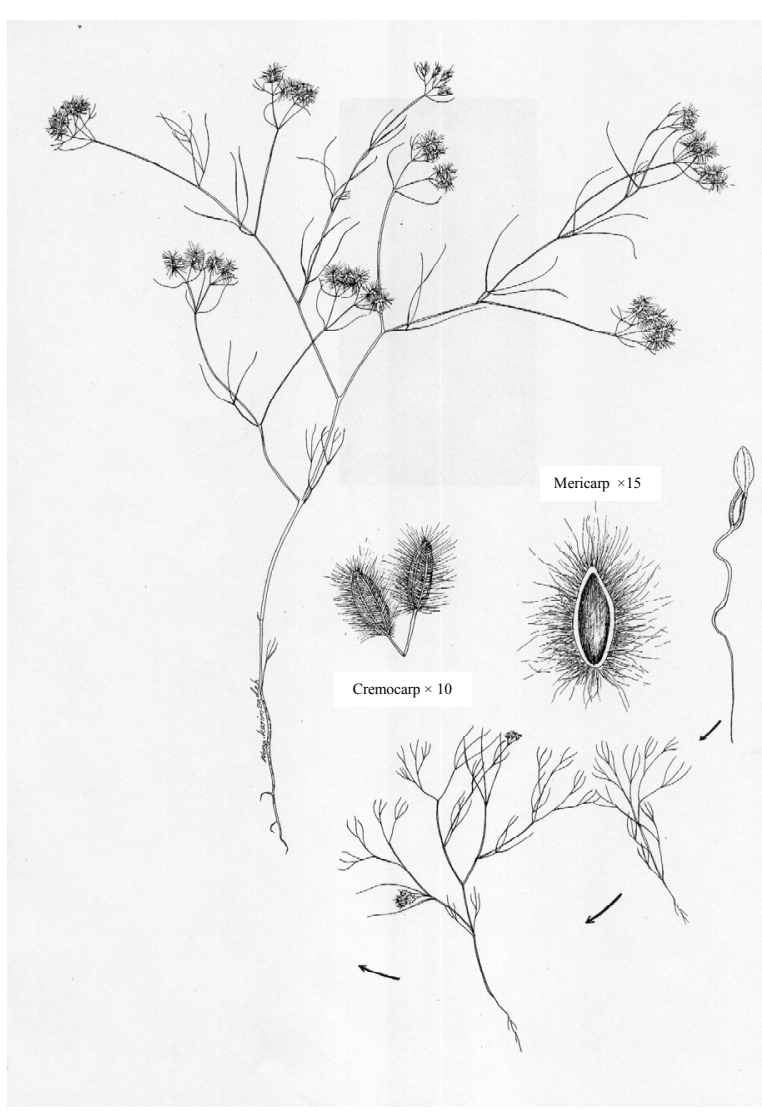

Fig. 5. Growth stages and fruit in Cuminum setifolium (Boiss.) Kos.-Pol., Apiaceae

tissue with only a row of cells along with a relatively thick cuticle (Fig. 6).

Thickness of the parenchyma layer located under epidermis measured approximately $2.6 \mu \mathrm{m}$ contained of 2-3 rows of irregular oblong cells without intercellular spaces. Vascular bundles were 10 in number and their formations were mostly solitary and partially radial chains.

Total diameter of xylem tissue was measured $65 \mu \mathrm{m}$ and maximum and minimum of vessels diameter were 2.4 and $0.6 \mu \mathrm{m}$ respectively. Rate of xylem to its companion fibers cells was high. Type of xylem formation was ring porous. Phloem tissue diameter measured approximately $4 \mu \mathrm{m}$ and any hard tissue associated with the phloem tissues were not observed (Fig. 6). Average diameter of the companion cells was approximately $0.6 \mu \mathrm{m}$.

Root tissue contained of hexagon shaped pith cells with $60 \mu \mathrm{m}$ diameter forming central layer of root. No secretory structures such as cells, tubes or canals were observed in root samples (Fig. 6).

\section{Stem structure}

In stem structure the following tissues were observed:

The epidermis tissue contained of a row of cells along with cuticle and stomata, lacking any hairs on the surface. The cortex layer including parenchyma cells contained 2 rows of irregular oblong cells which were a little thick and without intercellular spaces. Vascular bundles from type of 

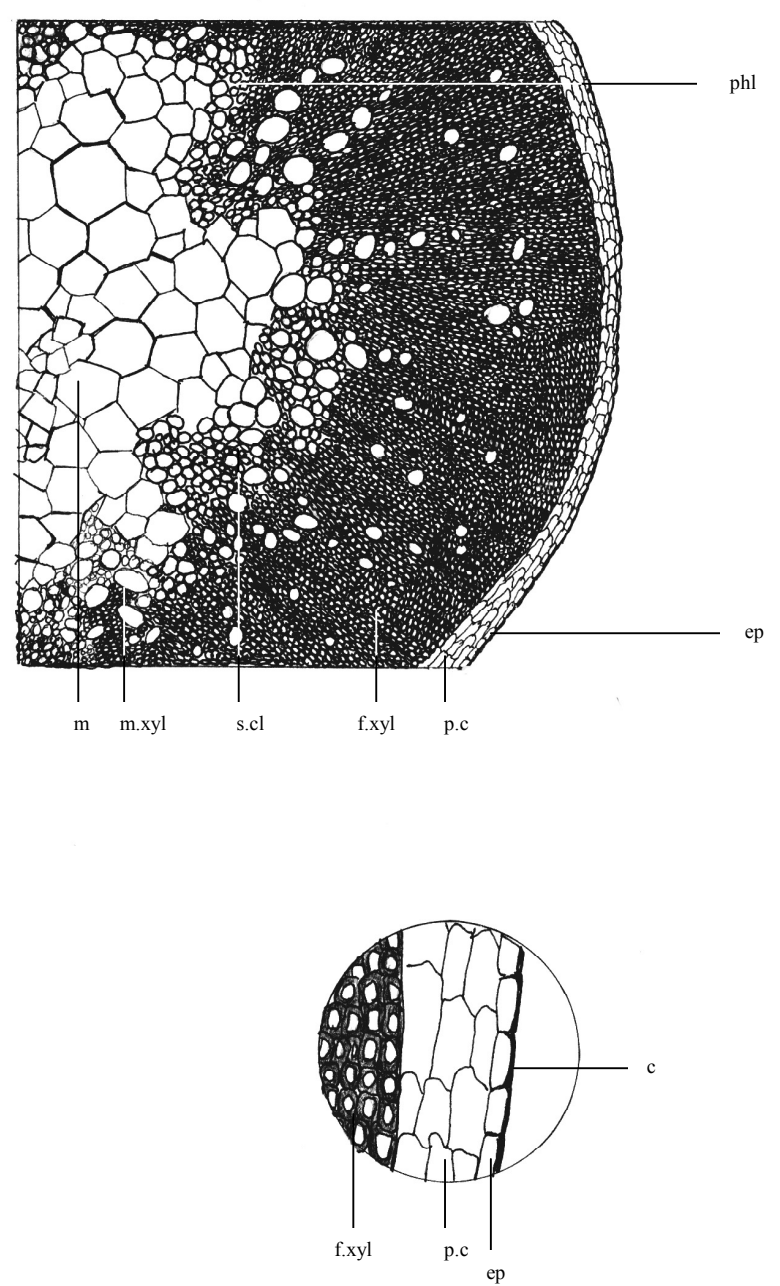

Fig. 6. Cross section of root in Cuminum setifolium (Boiss.) Kos.-Pol. $(\times 10)$; phl=phloem; $\mathrm{m}=$ pith; $\mathrm{m} . x y l=$ metaxylem; $\mathrm{s.cl}=$ secretory canals; f.xyl=xylem fiber; $\mathrm{p} . \mathrm{c}=$ cortex parenchyma; ep=epidermis; $c=$ cuticle bicollateral were observed under cortex layer which measured $10 \mu \mathrm{m}$ in diameter and distributional pattern of the bundles was ring porous (Fig. 7).

Phlogen layer was not active and therefore there was not any suberous tissue. Thickness of phloem tissue was measured $5 \mu \mathrm{m}$ and the total thickness was $50 \mu \mathrm{m}$. There was not hard or fibrous tissue associated with phloem tissue. Thickness of xylem tissue was measured $15 \mu \mathrm{m}$ and the total diameter $150 \mu \mathrm{m}$ in diameter. Maximum and minimum diameters of the vessels were 3 and $0.5 \mu \mathrm{m}$ respectively. Distributional pattern of the vessels was radial chains. Rate of xylem to its companion fibers was low. There were secretory canals in the existing sclerenchyma fibers. Also, most type of companion fibers was wide and thickness of fiber cells was measured $1 \mu \mathrm{m}$ (Fig. 8).

Central region of the stem formed a pith tissue with $55 \mu \mathrm{m}$ diameter contained of hexagonal cells without intercellular spaces but a part of the tissue was dissolved and became hollow. There were abundant sclerenchyma fibers between the vessels (Fig. 9). Additionally, projections of collenchyma tissue were observed at the angles of the stem which were approximately $4 \mu \mathrm{m}$ in diameter (Fig. 8). Also, there were secretory canals in sclerenchyma fibers (Fig. 9).

\section{Leaf structure}

In leaf structure the following tissues were observed:

Epidermis tissue contained of a row of cells along with cuticle and stomata without any hairs. Stomata type of epidermis was diacytic and distance between stomata was measured $5 \mu \mathrm{m}$ in average (Fig. 10). Type of parenchyma tissue was lateral scalariform arranged in 2 rows of oblong cells. Rate of scalariform tissue to spongy tissue was high. In vertical section of leaf, three vascular bundles from type of collateral were observed (Fig. 11). Also, sclerenchyma fiber cells existed above the bundles.

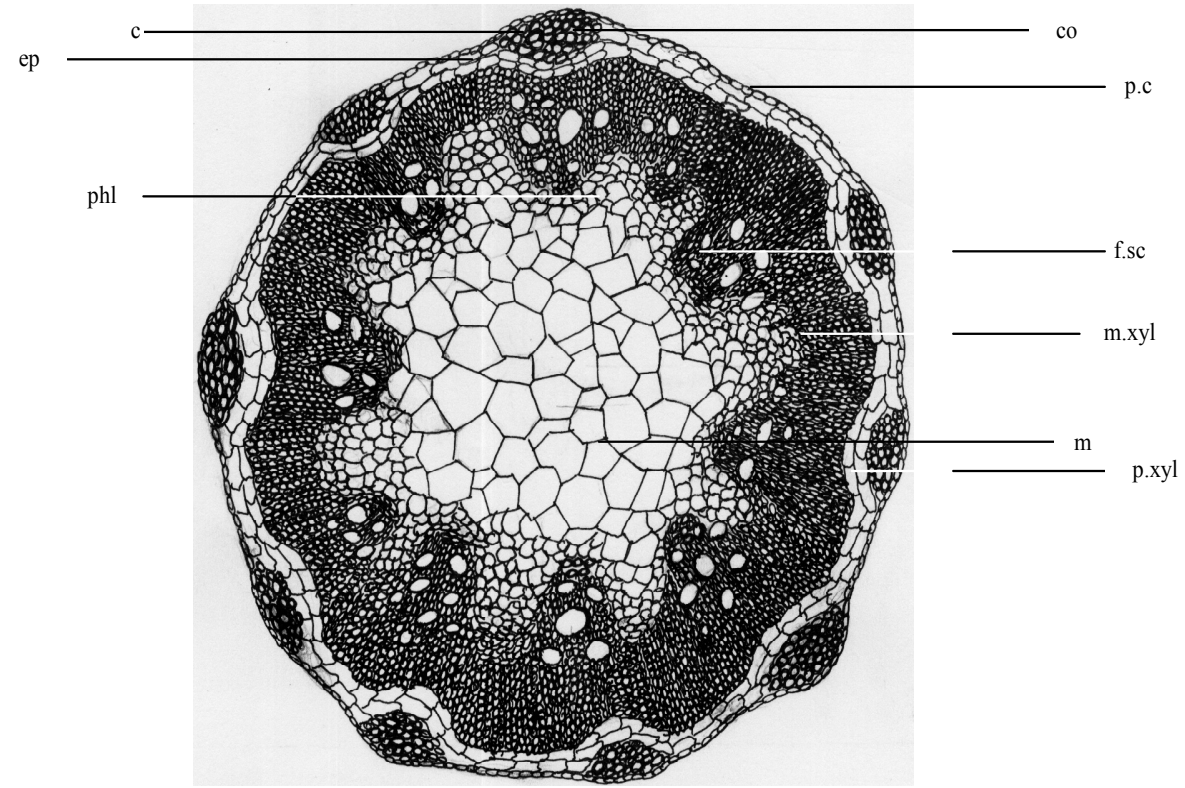

Fig. 7. Vascular bundles of stem in Cuminum setifolium (Boiss.) Kos.-Pol. $(\times 10)$; c=cuticle; ep=epidermis; phl=phloem; $\mathrm{co}=$ collenchyma; $\mathrm{p} . \mathrm{c}=$ cortex parenchyma; $\mathrm{f} . \mathrm{s}=$ =sclerenchyma fiber; $\mathrm{m} . \mathrm{xyl}=$ metaxylem; $\mathrm{m}=$ pith; .xyl=protoxylem 
34

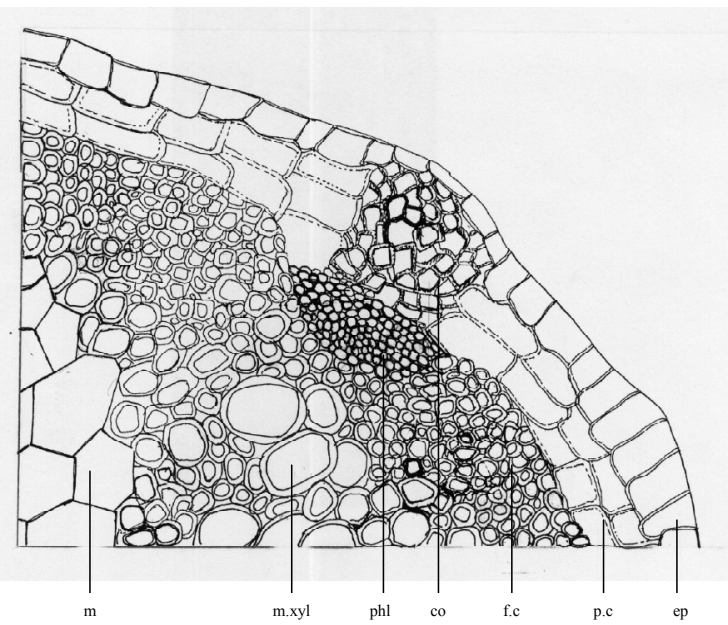

Fig. 8. Collenchyma tissue of stem in Cuminum setifolium (Boiss.) Kos.-Po $(\times 40) ; \mathrm{m}=$ pith; $\mathrm{m} . x y l=$ metaxylem; phl=phloem; $\mathrm{co}=$ collenchyma; $\mathrm{f} . \mathrm{c}=$ cortex fiber; $\mathrm{p} . \mathrm{c}=$ cortex parenchyma; $\mathrm{ep}=$ epidermis

\section{Discussion}

Improvement of Apiaceae (Umbelliferae) plants under the traditional breeding procedure is generally slow, laborious and time consuming (Hunault et al., 1989). Additionally, efforts to improve cumin have been constrained by the unavailability of genetic diversity for some desirable traits (Tawfik and Noga, 2002). Regarding to the structural features, chromosome number and vegetative form of the plant, it appears that white cumin is closely related to common cumin (caraway) and most probably evolved from it as a wild ancestor in nature. Production of green cumin is limited due to several biotic stresses of which the kaphra beetle (Trogoderma granarium) and wilting disease (Fusarium oxysporum) are the most serious (Agrawal,

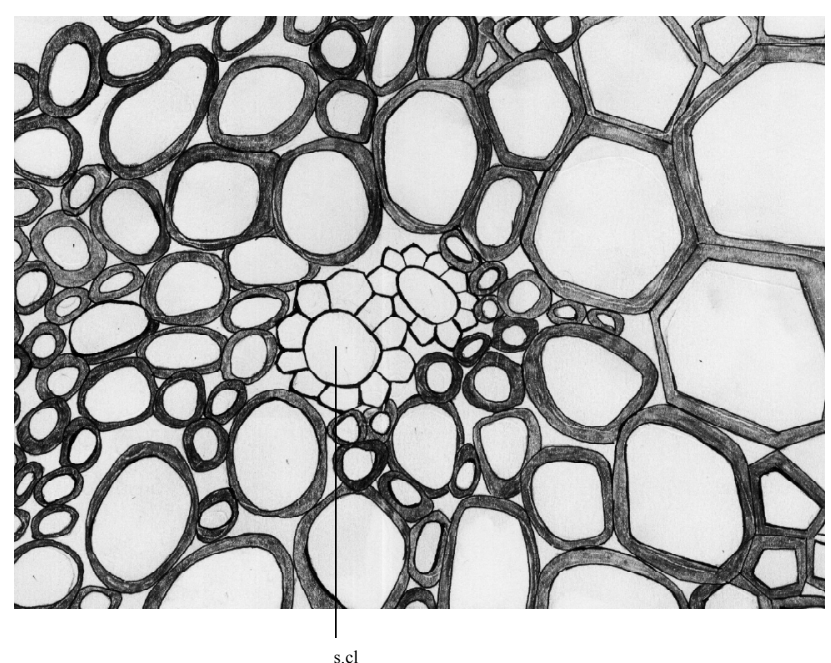

Fig. 9. Secretory canals between stem fibers of Cuminum setifolium (Boiss.) Kos.-Pol. (×40); s.cl=secretory canals

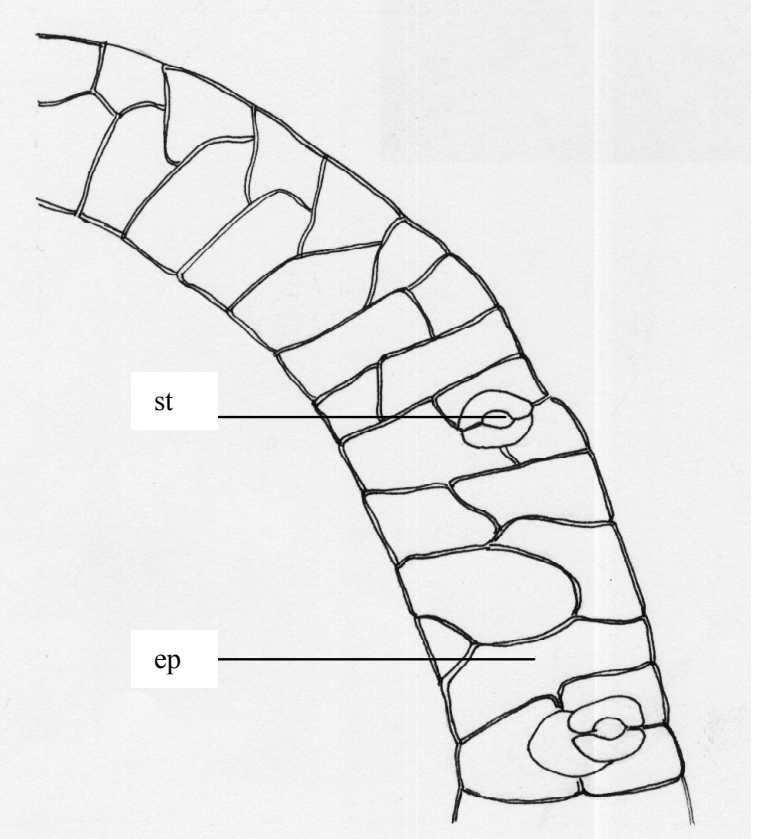

Fig. 10. Stomata in epidermis of Cuminum setifolium (Boiss.) Kos.-Pol. $(\times 40)$; st=stomata; ep=epidermis

1996; Champawat and Pathak, 1990). Therefore, white cumin as a wild type which may be useful in future studies for the improvement of green cumin with cross pollination for obtaining hybrids between them as well as genetic manipulation for finding strains with superior characteristics such as tolerance to disease, pests, drought and salinity, improved growth and development, increase of yield and other parameters used in the crop production. Generally, Umbeliferae species possess antimicrobial properties (Kafi et al., 2002; Theoblad, 1971). Microscopic observation of the root structure showed a lack of secondary structures and showing epidermis tissue with only a row of cells along with relatively thick cuticle and for stem and leaf structure with stomata without any hairs. Parenchyma cells contained 2-3 rows of irregular oblong cells with little thick

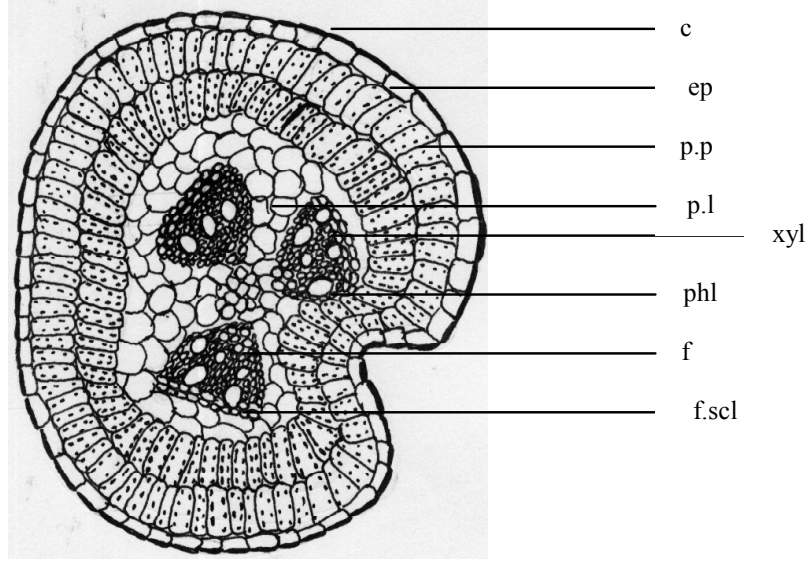

Fig. 11. Cross section of leaf in Cuminum setifolium (Boiss.)

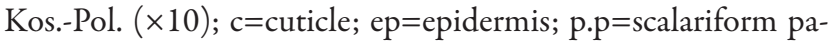
renchyma; $\mathrm{p} . \mathrm{l}=$ spongy parenchma; $\mathrm{xyl}=\mathrm{xylem} ; \mathrm{phl}=\mathrm{phloem} ; \mathrm{f}=$ vascular bundle; f.sc $=$ sclerenchyma fiber 
and without intercellular spaces. The type of stomata present in the epidermis was diacytic and distance between stomata was measured $5 \mu \mathrm{m}$ in average. The fruit in the Umbeliferae is a kind of nut known as a schizocarp which is divided into two mericarps bearing one seed in each of them. The mericarps usually have $4-5$ secondary longitudinal ridges which sometimes are winged or crested and separated by valleculae. Resin canals are almost always present. Mericarps are fused with a slender stipe known as a carpophore separating mericarps when matured (Heywood and Dakshini, 1971; Hickey and King, 1981; Mozaffarian, 1983). There is not information about white cumin (Cuminum setifolium) except distribution and botanical description (Mozaffarian, 1983; Rechinger, 1987). The effects of different treatment on seed germination showed the significant highest germination percentage $(54.4 \%)$ and germination rate $(6.4 \%)$ which were obtained from seeds that had exposed for 3 weeks at $4^{\circ} \mathrm{C}$ after omitting the seeds' hairs. Without omitting the seeds' hairs, germination was $7.42 \%$ for seeds exposed for 10 weeks at $4^{\circ} \mathrm{C}$. Other treatments such as stratification, gyberlic acid, $\mathrm{cy}$ tokinin, potassium nitrate, washing and light treatments did not cause the seed to germinate. Seed dormancy is one of crop obstacles to be cultured widely. This dormancy is embryonic and only cold treatment can cause the seed to germinate.

\section{Acknoledgements}

We are grateful to Razavi-Khorasan Agricultural and Natural Resources Research Center of Iran for helpful assistance to do this research.

\section{Refrences}

Agrawal S (1996). Volatile oil constituents and wilt resistance in cumin (Cuminum cyminum L.). Curr Sci 71:177-178.

Champawat RS, Pathak VN (1990). Field screening of cumin germplasm against Fusarium oxysprium f. sp cumini. J Arecanut Spices 13:142.
Ebrahimie E, Habashi AA, Ghareyazie B, Ghannadha M, Mohammadi M (2003). A rapid and efficient method for regeneration of plantlets from embryo explants of cumin. Plant Cell Tiss Org Cult 75:19-25.

Heywood VH, Dakshini KM (1971). Fruit structure in the Umbelliferae, p. 215-225. In: Heywood VH (Eds.). The biology and chemistry of the Umbelliferae. Academic press.

Hickey M, King EJ (1981). 100 families of flowering plants. p. 299-301.

Hunault G, Desmarest P, Manoir JD (1989). Foeniculum vulgare Miller: cell culture, regeneration and the production of anethole, p. 185-212. In: Bajaj YPS (Eds.). Biotechnology in Agriculture and Forestry, Medicinal and Aromatic Plants II. Springer-Verlag, Berlin, Germany.

Kafi M, Rashed Mohasel MH, Koocheki AR, Mollafilabi AA (2002). Cumin production and processing. Mashad Ferdowsi University Press.

Mozaffarian V (1983). The family of Umbelliferae in Iran. Pub. Research Institute of Forest and Rangelands 35:146-147.

Rechinger KH (1987). Flora Iranica. Akademische Druck-U. Verlagsanstalt Graz-Austria 162:140-142.

Tawfik AA, Noga G (2002). Cumin regeneration from seedling derived embryogenic callus in response to amended kinetin. Plant Cell Tiss Org Cult 69:35-40.

Theoblad WL (1971). Comparative anatomical and developmental studies in the Umbelliferae, p. 178-196. In: Heywood VH (Eds.). The biology and chemistry of the Umbelliferae. Academic Press.

Tripathi L, Tripathi JN (2003). Role of biotechnology in medicinal plants. Tropical J Pharma Res 2(2):243-253. 